\title{
Hepatoprotective effect of Descurainia sophia seed extract against paracetamol-induced oxidative stress and hepatic damage in mice
}

\author{
Pedram Moshaie-Nezhad ${ }^{1 \oplus}$, Maryam $\operatorname{Iman}^{1^{*}}{ }^{\circledR}$, Firouz Faed Maleki ${ }^{2}$, Ali Khamesipour ${ }^{3}$ \\ ${ }^{1}$ Chemical Injuries Research Center, Systems Biology and Poisonings Institute, Baqiyatallah University of Medical Sciences, Tehran, Iran. \\ ${ }^{2}$ Department of pharmacology, Babol Branch, Islamic Azad University, Babol, Iran \\ ${ }^{3}$ Center for Research and Training in Skin Diseases and Leprosy, Tehran University of Medical. Sciences, Tehran, Iran
}

\section{A R T I C L E I N F O}

Article Type:

Original Article

\section{Article History:}

Received: 12 January 2018

Accepted: 20 August 2018

\section{Keywords:}

Descurainia sophia

Hepatotoxicity

Medicinal plant

Oxidative stress

Hepato-protective effect

\begin{abstract}
A B S T R A C T
Introduction: In this study, we aimed to evaluate the protective effects of Descurainia sophia seed extract on paracetamol-induced oxidative stress and acute liver injury in mice.

Methods: Sixty male Swiss albino mice were divided into 6 groups, group I: as control group received $\mathrm{NaCl} 9 \%$. Group II: as paracetamol group received paracetamol intraperitoneally (i.p.) $(500 \mathrm{mg} / \mathrm{kg})$. Groups III to VI as treatment groups received different doses of D. sophia seed extract $(\mathrm{T} 1=50, \mathrm{~T} 2=100, \mathrm{~T} 3=200$ and $\mathrm{T} 4=300 \mathrm{mg} / \mathrm{kg}$, respectively). Twenty-four hours after the paracetamol administration, the mice were sacrificed under mild anesthesia and their blood samples were collected to estimate serum alkaline phosphatase (ALP), aspartate aminotransferase (AST), alanine aminotransferase (ALT), total bilirubin and malondialdehyde (MDA) levels. Their livers were also removed for histopathological examinations.

Results: Pretreatment of mice with $D$. sophia seed extract, significantly prevented the paracetamol induced elevation in the levels of serum ALT, AST and ALP, total bilirubin and MDA $(P<0.05)$. The results of histopathologic studies were consistent with the above findings. Conclusion: Descurainia sophia seed extract has a protective effect against paracetamol induced oxidative damage and acute hepatotoxicity in mice.
\end{abstract}

Implication for health policy/practice/research/medical education:

Results demonstrate that $D$. sophia seed extract is able to limit the paracetamol-induced oxidative and hepatic damages in the liver. Further studies are required to confirm the mechanisms responsible for hepatoprotective activity.

Please cite this paper as: Moshaie-Nezhad P, Iman M, Faed Maleki F, Khamesipour A. Hepatoprotective effect of Descurainia sophia seed extract against paracetamol-induced oxidative stress and hepatic damage in mice. J Herbmed Pharmacol. 2018;7(4):267-272. doi: 10.15171/jhp.2018.40.

\section{Introduction}

Liver is the most important organ for detoxification and deposition of endogenous and exogenous materials (1). Hepatic injuries are common sequela of liver diseases such as viral infection, hepatotoxins, xenobiotics, drugs, alcoholism and food poisoning which can devastate liver functions easily (2).

Paracetamol (acetaminophen, APAP) is widely used as an antipyretic and analgesics agent (3). It is wellknown to induce hepatic toxicity when used in a high doses. Paracetamol toxicity usually start with chest pain, vomiting, diarrhea, and sometimes shock and in excessive consumption causes hepatic failure (4) as well as myocardial and kidney injuries (5). When ingested at a therapeutic dose, paracetamol is metabolized by a cytochrome P450 and detoxified by glucuronidation as well as sulfation whereas $\mathrm{N}$-acetyl-p-benzoquinone imine (NAPQI) is conjugated with glutathione (GSH) (6). On the other hand, high doses saturates the detoxication pathways of paracetamol due to glucuronidation and sulfation insufficiency. Thus, excessive drug accumulation leads to GHS depletion. Exhausted GSH level allows free NAPQI to bind with other targeted cellular proteins which aggravate cellular oxidative stress and indulge in the 
cellular necrosis process (7).

Descurainia sophia seed, also known as flixweed, is a member of Brassicaceae family. It grows in most parts of the world especially in Asia, Europe, northern Africa, and North America. It is a popular herbal medicine used in China (8), India and Iran for treatment of various diseases. Some medical use of D. sophia extracts include treatment of asthma and cough, promotion of urination, alleviation of edema and strengthening of cardiac function. It is also used as analgesic, purgative, febrifuge, antipruritic, anthelmintic (9), expectorant, astringent, litholytic agent (10) and bleeding preventor (11). D. sophia seeds has also been reported to be used as laxative and for alleviation of skin inflammation and excretion of renal calculus $(12,13)$. The flowers and leaves are used as astringent and obviator of vitamin C deficiency (14). A few studies have completed on medical efficacy and mechanism actions of this plant $(8,15)$.

Paracetamol poisoning is still a major problem in some countries which accompanies side effects especially in high doses. Due to lack of effective medication for treatment of liver diseases and the increasing use of chemicals, search for a new treatment especially natural one with less side effect is essential. Hence, in the current study, the protective effect of $D$. sophia seed extract on paracetamol induced oxidative damage and hepatic injury was evaluated in a murine model.

\section{Material and Methods}

Chemicals

Acetaminophen powder was purchased from SigmaAldrich (sigma-A5000). Malondialdehyde (MDA), was measured by Zell bio GmbH kits (Germany).

\section{Animals}

Male Swiss albino mice (6-8 weeks old), weighting 20$25 \mathrm{~g}$ were purchased from Pasteur Institute of Iran. Mice were kept under standard condition $\left(23 \pm 2^{\circ} \mathrm{C}\right)(55 \pm$ $10 \%$ humidity) with $12 \mathrm{~h}$ light/dark cycle and provided standard pellet diet and free access to water during the experiment. The animals acclimatized to the environment for 1 week before the initiation of the experiment. The experimental design was approved by the Animal Ethics Committee of Islamic Azad University, Babol branch, Babol, Iran.

\section{Preparation of plant extract}

Descurainia sophia seed extract was purchased from an herbal pharmacy in Amol, Iran and Voucher specimen was deposited at the Herbarium of the Faculty of Pharmacy, Isfahan University of Medical Sciences, Isfahan, Iran (No. 2834). In order to prepare the required extract, the dried seeds were pulverized into fine powder using a homemade grinder, the powdered grain was poured into an Arlene and then ethyl alcohol $96 \%$ was added $(22 \mathrm{~g}$ per $21 \mathrm{~mL}$ of ethyl alcohol) and placed on a shaker for 24 hours. The extract was condensed using a rotary device to remove alcohol, and then was placed in an oven for 22 hours at $61^{\circ} \mathrm{C}$ to dry (16).

\section{Treatment schedule}

Mice were randomly divided into 6 groups of ten mice as follows:

Group I: Control group: mice were orally administered $\mathrm{NaCl} \mathrm{9 \%} \mathrm{(200} \mathrm{mg/kg)} \mathrm{for} 7$ days.

Group II: Paracetamol group: mice were received a single intraperitoneal (i.p.) injection $(500 \mathrm{mg} / \mathrm{kg}$ ) on the eighth day, paracetamol powder was dissolved in distil water at $60^{\circ} \mathrm{C}$ and then cooled to $37^{\circ} \mathrm{C}$.

Group III to VI: Treatment groups: including 4 groups with different doses of $D$. sophia seed extract ( $\mathrm{T} 1=50$, $\mathrm{T} 2=100, \mathrm{~T} 3=200$ and $\mathrm{T} 4=300 \mathrm{mg} / \mathrm{kg}$, respectively). Mice were received $D$. sophia seed extract twice a day every 12 hours for 7 days. The doses and the duration of treatment of paracetamol and D. sophia seed extract were selected based on previous reports $(8,17,18)$.

After 7 days of treatment, all groups except control group received paracetamol on day 8 and 24 hours after the paracetamol administration, mice were anesthetized using ether. The blood was withdrawn from the mice heart. Each blood sample was collected into separate vial and used to titrate the serum level of ALT, AST and ALP, total bilirubin and MDA. The mice livers were removed and kept in $10 \%$ formalin buffer for histopathological examination.

\section{Biochemical analysis of blood serum \\ Liver enzymes and total bilirubin measurement}

The serum was separated by centrifugation centrifuging at $3500 \mathrm{rpm}$ for $10 \mathrm{~min}$. The levels of serum alkaline phosphatase (ALP), aspartate aminotransferase (AST), alanine aminotransferase (ALT) and total bilirubin were measured spectrophotometrically by auto analyzer machine (alfa classic), using commercial kits (Pars Azmon kits).

\section{Malondialdehyde assay}

Measurement of malondialdehyde (MDA) level was done using commercial chemical colorimetrical assay kit (MDA assay kit; ZellBio GmbH, Ulm, Germany) following manufacturer's protocol. It uses the MDA-TBA adduct formed by the reaction of MDA and TBA, under high temperature. MDA was measured in acidic media and temperature of $90-100^{\circ} \mathrm{C}$, calorimetrically at $535 \mathrm{~nm}$. This method titrates the MDA with $0.1 \mu \mathrm{M}$ sensitivity. The intra- and inter-assay coefficient of variation was $5.8 \%$ and $7.6 \%$, respectively.

Histopathological examination

The stored livers were used to prepare sections using 
a rotary microtome at $5 \mu \mathrm{m}$, then were stained with hematoxylin and eosin (H\&E). The sections were examined under a light microscope. The various changes in histological features were graded (19).

Statistical analysis

Statistical analyses were done using SPSS version 22. The results were expressed as mean \pm standard error (SE) and one-way analyses of variance (ANOVA), followed by Duncan test. The statistical significance of difference was taken as $P \leq 0.05$.

\section{Results}

Liver enzymes (ALT, AST and ALP) and total bilirubin Treatment with paracetamol $(500 \mathrm{mg} / \mathrm{kg})$ caused a significant increase in the levels of ALT, AST, ALP, and MDA in comparison with the control group. Intraperitoenal injection of paracetamol produced evidence of hepatotoxicy. After administration of $D$. sophia seed extract, the level of ALT and AST in doses of 100, 200, $300 \mathrm{mg} / \mathrm{kg}$ significantly decreased in comparison with the ones of paracetamol group $(P<0.05)$. In regard to ALP level, group of T3 and T4 showed a significant reduction in comparison with the acetaminophen group also, there was no significant difference between group T3 and T4 as compared with the control group $(P>0.05)$. There was no significant difference in total bilirubin levels in different groups. Considering the levels of ALT, AST and ALP as the markers of efficacy, the most effective treatment was observed in the group which received $300 \mathrm{mg} / \mathrm{kg}$ of $D$. sophia seed extract in comparison with the control group (P>0.05) (Table 1).

Lipid peroxidation (MDA) activity

Chronic administration of acetaminophen induced a significant increase in the level of MDA. After administration of $D$. sophia seed extract a significant reduction was seen in groups of T3 and T4 compared to paracetamol group $(P<0.05)$ however, there was a significant difference between $\mathrm{T} 3$ and $\mathrm{T} 4$ groups as compared to the control group $(P<0.05)$ (Table 1)

Histologic examination

Figure 1 shows normal morphological picture under light microscope in the control group, which received only $\mathrm{NaCl} 9 \%$. In the groups of paracetamol and $\mathrm{T} 1$ (50 $\mathrm{mg} / \mathrm{kg}$ ) necrosis, hyperemia, vacuolar degeneration and infiltration of the inflammatory cells were observed which indicated a hepatocellular damage (Figure 1). In this regards, group T2 $(100 \mathrm{mg} / \mathrm{kg})$ was similar to paracetamol group with less damages (Figure 1). Mild necrosis vacuolar degeneration and infiltration of the inflammatory cells were observed in the group T3 $(300 \mathrm{mg} / \mathrm{kg})$. In the group T4 $(300 \mathrm{mg} / \mathrm{kg}$ ) only mild vacuolar degeneration and infiltration of the inflammatory cells were seen which may indicate that the treatment of $D$. sophia seed extract was effective (Figure 1). Histopathologic parameters of the liver tissues were graded in Table 2.

\section{Discussion}

Paracetamol is a well-known hepatotoxic agent in human and experimental animals $(20,21)$. At normal doses, the main elimination pathways of paracetamol are conjugation with glucuronide and sulfate (22). About $10 \%$ of paracetamol is oxidized through a cytogarlic chrome P450 dependent pathway to an electrophilic metabolite. NAPQI is regularly detoxified by GSH and finally eliminated through urine or gall as paracetamolcysteine, paracetamol-N-acetylcysteine. In high doses, the glucuronidation and sulfation routes become saturated and more extensive bio activation of paracetamol occurs within 1 to 2 hours, leading to depletion of hepatic GSH level. Following covalent binding of NAPQI to cellular macromolecules, membrane lipid peroxidation, and disturbance of intracellular calcium balance take place resulting in cell damage and/or necrosis $(23,24)$. There are several studies showing the toxicity of paracetamol in the liver $(25,26)$.

Table 1. Treatment with different doses of $D$. sophia (DS) seed extract $(50,100,200$ and $300 \mathrm{mg} / \mathrm{kg}$ ) on serum levels of ALT, AST, ALP, total bilirubin and MDA

\begin{tabular}{llllll}
\hline Groups & ALT(U/L) & AST(U/L) & ALP(U/L) & Total Bilirubin $(\mathrm{mg} / \mathrm{dL})$ & MDA $(\boldsymbol{\mu m})$ \\
\hline Control & $66.20 \pm 10.49^{\mathrm{a}}$ & $91.40 \pm 15.48^{\mathrm{a}}$ & $207.90 \pm 16.81^{\mathrm{a}}$ & $0.397 \pm 0.010^{\mathrm{a}}$ & $1.11 \pm 0.133^{\mathrm{a}}$ \\
Paracetamol $(500 \mathrm{mg} / \mathrm{kg})$ & $532.10 \pm 45.47^{\mathrm{d}}$ & $749.10 \pm 59.53^{\mathrm{e}}$ & $387.90 \pm 35.31^{\mathrm{c}}$ & $0.440 \pm 0.010^{\mathrm{c}}$ & $2.41 \pm 0.147^{\mathrm{d}}$ \\
DS $(50 \mathrm{mg} / \mathrm{kg})$ & $481.30 \pm 24.13^{\mathrm{d}}$ & $673.20 \pm 49.84^{\mathrm{e}}$ & $370.40 \pm 13.564^{\mathrm{c}}$ & $0.428 \pm 0.009^{\mathrm{bc}}$ & $2.26 \pm 0.172^{\mathrm{cd}}$ \\
DS $(100 \mathrm{mg} / \mathrm{kg})$ & $393.90 \pm 25.52^{\mathrm{c}}$ & $550.30 \pm 28.63^{\mathrm{ad}}$ & $344.90 \pm 34.14^{\mathrm{bc}}$ & $0.412 \pm 0.007^{\mathrm{abc}}$ & $2.02 \pm 0.151^{\mathrm{bcd}}$ \\
DS $(200 \mathrm{mg} / \mathrm{kg})$ & $266.60 \pm 19.89^{\mathrm{b}}$ & $397.70 \pm 36.76^{\mathrm{c}}$ & $271.20 \pm 21.91^{\mathrm{ab}}$ & $0.425 \pm 0.009^{\mathrm{abc}}$ & $1.93 \pm 0.079^{\mathrm{bc}}$ \\
DS $(300 \mathrm{mg} / \mathrm{kg})$ & $189.80 \pm 30.478^{\mathrm{b}}$ & $217.10 \pm 34.74^{\mathrm{b}}$ & $245.40 \pm 27.06^{\mathrm{a}}$ & $0.401 \pm 0.008^{\mathrm{ab}}$ & $1.66 \pm 0.138^{\mathrm{b}}$ \\
\hline
\end{tabular}

Abbreviations: DS, Descurainia sophia; AST, aspartate aminotransferase; ALT, alanine aminotransferase; ALP alkaline phosphatase; MDA, malondialdehyde.

Each value represents the mean \pm SD. abcd significant difference between the groups was shown after the Duncan post-test. Each letter represents a group. The confidence level is $95 \%$. 
Table 2. Histopathologic changes induced by Paracetamol and different doses of treatment groups of Descurainia sophia seed extract in liver tissue

\begin{tabular}{lcccc}
\hline Groups & Necrosis & Hyperemia & Vacuole degeneration & Infiltration of inflammatory cells \\
\hline Control & - & - & - \\
Paracetamol $(500 \mathrm{mg} / \mathrm{kg})$ & ++ & ++ & ++ \\
DS $(50 \mathrm{mg} / \mathrm{kg})$ & ++ & + & + & + \\
DS $(100 \mathrm{mg} / \mathrm{kg})$ & + & - & + \\
DS $(200 \mathrm{mg} / \mathrm{kg})$ & + & - & ++ \\
DS $(300 \mathrm{mg} / \mathrm{kg})$ & - & +
\end{tabular}
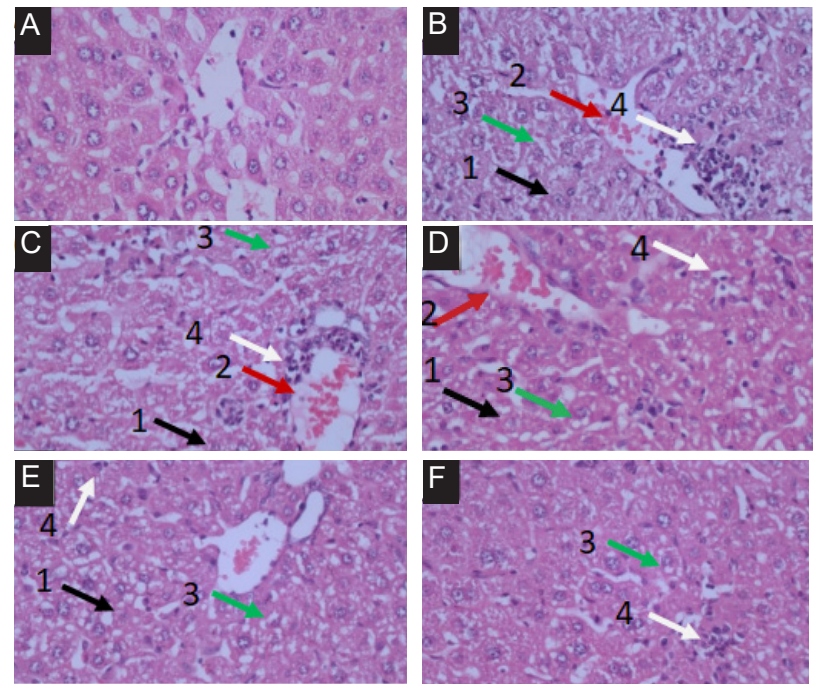

Figure 1. Histopathological observations; (A) Control, (B) Paracetamol; 1: Necrosis, 2: Hyperemia, 3: Vacuole degeneration, 4: Infiltration of inflammatory cells). (C) T1; 1: Necrosis, 2: Hyperemia, 3: Vacuole degeneration, 4: Infiltration of inflammatory cells), (D) T2; 1: Necrosis, 2: Hyperemia, 3: Vacuole degeneration, 4: Infiltration of inflammatory cells) (E) T3; 1: Necrosis, 3: Vacuole degeneration, 4: Infiltration of inflammatory cells), (F) T4; 3: Vacuole degeneration, 4: Infiltration of inflammatory cells). (Liver sections H\&E, magnification 40X).

The current results showed that administration of paracetamol at dose of $500 \mathrm{mg} / \mathrm{kg}$ caused acute liver damage in mice, with excessive elevation in serum ALT, AST and ALP activities as well as histopathological changes. These activities are consistent with the findings of Mehmetçik et al, which showed that MDA was a reactive aldehyde released during peroxidation of membrane phospholipids (27). Therefore, hepatic MDA level is used as an indicator of liver damages (28). In the present study paracetamol administration caused a significantly increase $(P<0.05)$ in the MDA level which was consistent with the results of other studies $(29,30)$.

The aim of the present study was to investigate the effect of $D$. sophia seed extract against paracetamol-induced oxidative stress and hepatotoxicity. It was observed that the administration of $D$. sophia seed extract inhibited the damages induced by paracetamol and elevation of the level of ALT, AST, ALP, total bilirubin and decreased the level of MDA.

Ning Zhou et al investigated the effect of D. sophia to find a new approach for the mechanism action of traditional Chinese medicine (TCM). They showed that the metabolomics method combined with split fractions of extract is a powerful approach to identify the pathologic changes of Chinese medicine syndrome and action mechanisms of TCM (8). In another study, the isolation and structural elucidation of a new sulphur glycoside (descurainoside) from D. sophia was shown. It was demonstrated that $D$. sophia relieves cough and asthma, promotes urination, alleviates edema, and enhances cardiac function (31). The results of the current study showed that histopathological examination was an indication of hepatic damages after administration of paracetamol including necrosis, hyperemia, vacuolar degeneration and infiltration of the inflammatory cells in the group of mice which received paracetamol. The histopathology of liver confirmed the protective effect of $D$. sophia seed extract in the group of mice in which the administration of paracetamol induced hepatic damages. The efficacy was shown by the reduction of livers' damages such as, necrosis, hyperemia, vacuolar degeneration and infiltration of the inflammatory cells, the effects were especially evident at the dose of $300 \mathrm{mg} / \mathrm{kg}$.

\section{Conclusion}

In summary, this study illustrated that D. sophia seed extract could be proposed to protect the liver against paracetamol-induced oxidative and hepatic damages in an animal model. Results demonstrate that D. sophia seed extract is able to limit the paracetamol-induced oxidative and hepatic damages in the liver. The extract showed a potential protective effect in all doses but the most significant protection was seen in dose of $300 \mathrm{mg} / \mathrm{kg}$. Further studies are required to confirm the mechanisms responsible for hepatoprotective activity.

\section{Acknowledgements}

The authors would like to appreciate Dr. Mohammad Hosseini for his technical assistance. 


\section{Authors' contributions}

PMN was the main researcher and performed the experiments. PMN, MI and FFM contributed to design of the study. MI supervised the research and AK revised the manuscript. All authors read the final version and confirmed the manuscript publication.

\section{Conflict of interests}

The authors declared no competing interests.

\section{Ethical considerations}

This project was approved by Baqiyatallah University of Medical ciences (ethics No. IR.BMSU.REC.1396.464).

\section{Funding/Support}

None.

\section{References}

1. Jaeschke H, Gores GJ, Cederbaum AI, Hinson JA, Pessayre D, Lemasters JJ. Mechanisms of hepatotoxicity. Toxicol Sci. 2002;65(2):166-76. doi: 10.1093/toxsci/65.2.166.

2. Hall PM, Plummer JL, Ilsley AH, Ahern MJ, Cmielewski PL, Williams RA. The pathology of liver injury induced by the chronic administration of alcohol and 'low-dose' carbon tetrachloride in Porton rats. J Gastroenterol Hepatol. 1994;9(3):250-6. doi: 10.1111/j.1440-1746.1994.tb01719.x.

3. James LP, Mayeux PR, Hinson JA. Acetaminophen-induced hepatotoxicity. Drug Metab Dispos. 2003;31(12):1499-506. doi: 10.1124/dmd.31.12.1499.

4. Song Z, McClain CJ, Chen T. S-Adenosylmethionine protects against acetaminophen-induced hepatotoxicity in mice. Pharmacology. 2004;71(4):199-208. doi: $10.1159 / 000078086$.

5. Kumar V, Abbas AK, Aster JC, Perkins JA. Robbins and Cotran pathologic basis of disease. Philadelphia, PA: Elsevier; 2015:96-104.

6. Cristani M, Speciale A, Mancari F, Arcoraci T, Ferrari D, Fratantonio D, et al. Protective activity of an anthocyaninrich extract from bilberries and blackcurrants on acute acetaminophen-induced hepatotoxicity in rats. Nat Prod Res. 2016:1-5. doi: 10.1080/14786419.2016.1160235.

7. Wang EJ, Li Y, Lin M, Chen L, Stein AP, Reuhl KR, et al. Protective effects of garlic and related organosulfur compounds on acetaminophen-induced hepatotoxicity in mice. Toxicol Appl Pharmacol. 1996;136(1):146-54. doi: 10.1006/taap.1996.0018.

8. Zhou N, Sun YP, Zheng XK, Wang QH, Yang YY, Bai ZY, et al. A Metabolomics-based strategy for the mechanism exploration of traditional Chinese medicine: Descurainia sophia seeds extract and fractions as a case study. Evid Based Complement Alternat Med. 2017;2017:2845173. doi: 10.1155/2017/2845173.

9. Barnes J, Anderson LA, Phillipson JD. Herbal medicines: a guide for healthcare professionals. Pharm J. 2003;131-43.

10. Mirheidar H. Maaref giahi (Plant Knowledge). Tehran, Iran: Daftare Nashre Farhange Eslami; 2005:172-3. [Persian].

11. Lee YJ, Kim NS, Kim H, Yi JM, Oh SM, Bang OS, et al. Cytotoxic and anti-inflammatory constituents from the seeds of Descurainia sophia. Arch Pharm Res.
2013;36(5):536-41. doi: 10.1007/s12272-013-0066-x.

12. Mohamed NH, Mahrous AE. Chemical constituents of Descurainia sophia L. and its biological activity. Records of Natural Products. Rec Nat Prod. 2009;3(1):58-67.

13. Wang AQ, Wang XK, Li JL, Cui XY. [Isolation and structure identification of chemical constituents from the seeds of Descurainia sophia (L.) Webb ex Prantl]. Yao Xue Xue Bao. 2004;39(1):46-51.

14. Nimrouzi M, Zarshenas MM. Phytochemical and pharmacological aspects of Descurainia sophia Webb ex Prantl: modern and traditional applications. Avicenna J Phytomed. 2016;6(3):266-72.

15. Xie W, Ji XM, Pang ZX, Wang SJ. Establishment and evaluation of the rat model of harmful fluid retention in the upper jiao. World Journal of Integrated Traditional and Western Medicine. 2015;10(4):767-70.

16. Johari H, Sharifi E, Ansari N, Hosseini M, Amiri F. Effect of hydro alcoholic ginger extracts on the body weight, testis weight and spermatogenesis in male rats undergoing chemotherapy with cyclophosphamide. J Shahid Sadoughi Univ Med Sci. 2010;17(5):365-74.

17. Forouzandeh H, Azemi ME, Rashidi I, Goudarzi M, Kalantari H. Study of the Protective Effect of Teucrium polium L. Extract on Acetaminophen-Induced Hepatotoxicity in Mice. Iran J Pharm Res. 2013;12(1):1239.

18. Girish C, Koner BC, Jayanthi S, Ramachandra Rao K, Rajesh B, Pradhan SC. Hepatoprotective activity of picroliv, curcumin and ellagic acid compared to silymarin on paracetamol induced liver toxicity in mice. Fundam Clin Pharmacol. 2009;23(6):735-45. doi: 10.1111/j.14728206.2009.00722.x.

19. Aydin G, Gokçimen A, Oncu M, Cicek E, Karahan N, Gokalp O. Histopathologic changes in liver and renal tissues induced by different doses of diclofenac sodium in rats. Turk J Vet Anim Sci. 2003;27(5):1131-40.

20. Larson AM, Polson J, Fontana RJ, Davern TJ, Lalani E, Hynan LS, et al. Acetaminophen-induced acute liver failure: results of a United States multicenter, prospective study. Hepatology. 2005;42(6):1364-72. doi: 10.1002/hep.20948.

21. Cakir E, Akgul OE, Aydin I, Cayci T, Kurt YG, Onguru O, et al. The association between neopterin and acetaminopheninduced nephrotoxicity. Ren Fail. 2010;32(6):740-6. doi: 10.3109/0886022x.2010.486500.

22. Dahlin DC, Nelson SD. Synthesis, decomposition kinetics, and preliminary toxicological studies of pure $\mathrm{N}$-acetylp-benzoquinone imine, a proposed toxic metabolite of acetaminophen. J Med Chem. 1982;25(8):885-6. doi: 10.1021/jm00350a001.

23. Corcoran GB, Mitchell JR, Vaishnav YN, Horning EC. Evidence that acetaminophen and $\mathrm{N}$-hydroxyacetaminophen form a common arylating intermediate, $\mathrm{N}$-acetyl-p-benzoquinoneimine. Mol Pharmacol. 1980;18(3):536-42.

24. Mitchell JR, Jollow DJ, Potter WZ, Gillette JR, Brodie BB. Acetaminophen-induced hepatic necrosis. IV. Protective role of glutathione. J Pharmacol Exp Ther. 1973;187(1):2117.

25. Bessems JG, Vermeulen NP. Paracetamol (acetaminophen)induced toxicity: molecular and biochemical mechanisms, analogues and protective approaches. Crit Rev Toxicol. 
2001;31(1):55-138. doi: 10.1080/20014091111677.

26. Janbaz KH, Saeed SA, Gilani AH. Studies on the protective effects of caffeic acid and quercetin on chemical-induced hepatotoxicity in rodents. Phytomedicine. 2004;11(5):42430. doi: 10.1016/j.phymed.2003.05.002.

27. Mehmetcik G, Ozdemirler G, Kocak-Toker N, Cevikbas U, Uysal M. Effect of pretreatment with artichoke extract on carbon tetrachloride-induced liver injury and oxidative stress. Exp Toxicol Pathol. 2008;60(6):475-80. doi: 10.1016/j. etp.2008.04.014.

28. Dundarz MR, Turkbay T, Akay C, Sarici SU, Aydin A, Denli M, et al. Antioxidant enzymes and lipid peroxidation in adolescents with inhalant abuse. Turk J Pediatr.
2003;45(1):43-5.

29. Wang C, Xiao D, Zhao H, Ge P. Effect of lipid peroxidation in benzene in halation of mice. Acta Academiae Medicinae Bengbu. 1997;22(3):143-5.

30. Mohamed HA, El-Sayed IH, Moawad M. Protective effect of Nigella sativia seeds against dimethylaminoazobenzene (DAB) induced liver carcinogenesis. Cancer Biol.2011;1(1):45-50.

31. Sun K, Li X, Liu JM, Wang JH, Li W, Sha Y. A novel sulphur glycoside from the seeds of Descurainia sophia (L.). J Asian Nat Prod Res. 2005;7(6):853-6. doi: $10.1080 / 1028602042000204072$ 